\title{
Odešel Jan Průcha
}

Smutná zpráva, že po krátké nemoci 12. června 2021 ve věku 86 let zemřel profesor PhDr. Jan Průcha, DrSc., dr. h. c., zasáhla jeho nejbližší kolegy i celou českou i zahraniční pedagogickou komunitu.

Jan Průcha nesporně ovlivnil několik generací českých pedagogů. Jeho publikace jsou frekventovaně citovány v odborných publikacích i diplomových a disertačních pracích. Znají jej i nejmladší studenti, kteří se s ním již osobně nesetkávali. Pro ty, kdo s ním mohli spolupracovat a diskutovat, znamená jeho odchod citelnou ztrátu významné vưdčí osobnosti oboru, náročného kritika a kolegy, ochotného podpořit a ocenit výsledky či pedagogickou zdatnost jiných. $\mathrm{S}$ jeho jménem jsou spjata zásadní díla v oblasti srovnávací pedagogiky, metodologie pedagogického výzkumu, školního i předškolního vzdělávání, andragogiky, interkulturního vzdělávání a zejména psycholingvisti-

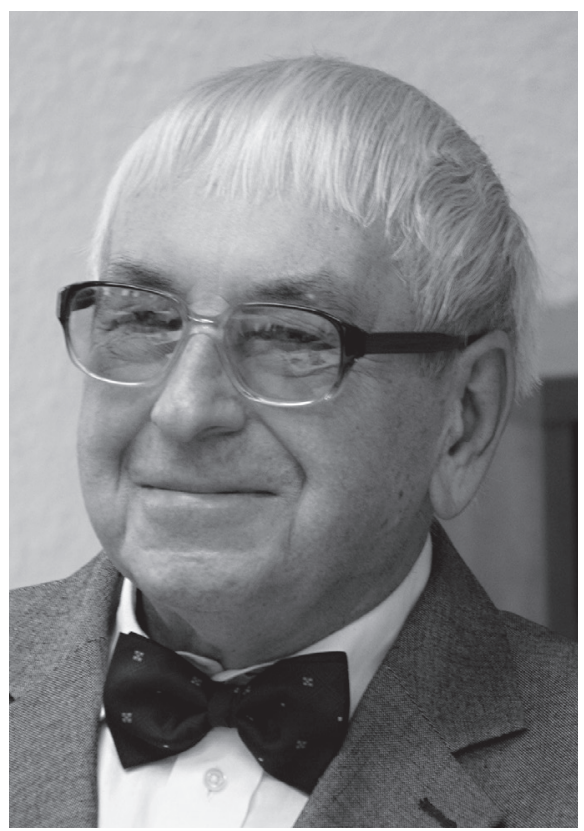

Prof. Jan Průcha

(foto archiv nakladatelství Portál). ky a psychodidaktiky. Pro obor nezbytné slovníkové a encyklopedické publikace, jichž byl hlavním autorem nebo editorem, zná každý učitel i student. Výrazný podíl měl Jan Průcha na transformaci české pedagogické vědy po roce 1989 a na aktivitách České asociace pedagogického výzkumu, jejíž vznik inicioval. Jana jsme znali také jako vtipného glosátora, člověka s poetickou duší, zájmem o historii a aktuální dění ve společnosti. Aktivně sportoval a udržoval se v obdivuhodně dobré fyzické kondici do vysokého věku. I když $v$ posledních letech si věk vybíral daň na tělesné zdatnosti, jeho mentální kondice, kterou mu mohli mladší závidět, zasluhovala obdiv. Neúnavně pracoval, vydával nové publikace, účastnil se práce redakčních rad časopisů Pedagogika a Orbis scholae, 
104 byl žádaným plenárním referentem na konferencích, recenzentem a oponentem při habilitačních a profesorských řizeních.

Nahlédnutí do životní a profesní dráhy může poskytnout jen dílek mozaiky utvářející obraz osobnosti, překračující limity dané dobou, v níž Jan Průcha žil a přispíval k formování „moderni““ pedagogiky, využívaje potenciál badatele a organizátora aktivit vědecké komunity. Narodil se 23. listopadu 1934 na okraji Prahy, v níž prožil celý život, ač bytostně tíhl k venkovu, který mu skýtal zázemí pro aktivní relaxaci a z něhož čerpal energii i poznatky o české realitě.

Svou profesní dráhu zahájil po studiích bohemistiky a mad'arštiny na tehdejší Filologické fakultě UK jako učitel na 2. stupni tehdejší osmiletky, později na střední škole. Učitelské zkušenosti ovlivnily jeho zájem o školní vzdělávání, který se promítl i do jeho pozdějších výzkumných projektů. $V$ šedesátých letech minulého století absolvoval vědeckou aspiranturu v Ústavu pro jazyk český Československé akademie věd (ÚJČ ČSAV), kde pak působil několik let jako vědecký pracovník. Zde obrátil pozornost k psycholingvistice, inspirován sovětskými i zahraničními autory. Přeložil Vygotského zásadní díla publikovaná pak česky jako Myšlení a řeč (1971) a Vývoj vyšších psychických funkcí (s M. Sedlákovou, 1976). Jeho publikace věnované psycholingvistice, jež byly přeloženy $i$ do angličtiny a němčiny a vydány $v$ několika západoevropských zemích, zprostředkovávaly odborné vazby mezi Západem a Východem, $v$ té době limitované vzhledem $\mathrm{k}$ bipolárnímu rozdělení světa i vědy. $\mathrm{V}$ době působení v ÚJČ ČSAV získal Jan Průcha titul kandidáta věd.

V letech 1969-1989 pracoval v Pedagogickém ústavu Jana Amose Komenského ČSAV (PÚJAK) v oddělení teorie vzdělávání. Brzy se prosadil jako vưdčí osobnost ve výzkumu školního vzdělávání. $V$ rámci státního plánu základního výzkumu koordinoval projekt zaměřený na obsah vzdělávání. Věnoval se nejprve jazykovému vzdělávání, následně v širším interdisciplinárním konceptu formoval teorii víceúrovňového procesu transformace vědeckých poznatků do obsahů školního vzdělávání. Pod jeho vedením byly analyzovány procesy tvorby učiva od koncepce a projektování přes realizaci ve třídě až po úroveň osvojení žáky a hodnocení výsledků. $V$ domácím prostředí publikoval s kolektivem řešitelů řadu zpráv a studií, jejichž relevantnost dokládá vysoká a dlouhodobá citovanost. Nutno dodat, že česká teorie obsahu vzdělávání byla srovnatelná s víceúrovňovou teorií kurikula, aplikovanou v mezinárodních výzkumech a studiích TIMSS a jinde. I když se oba př́istupy vyvíjely nezávisle a česká varianta zůstala, vzhledem $\mathrm{k}$ politickým a ideovým bariérám, neznámou západní odborné komunitě, ve východním bloku vyvolala Průchova teorie diskusi a inspirovala řadu výzkumných projektů.

Aktivní a cílená korespondence se zahraničními odborníky byla důležitým zdrojem Průchova mimořádného odborného přehledu. V období působení v PÚJAK rozvíjel Jan Průcha spolupráci s institucemi pedagogického výzkumu v Československu, s elitními didaktiky na fakultách vzdělávajících učitele i s resortními ústavy ve školství, zejména s tehdejším Výzkumným ústavem odborného školství (Vúoš). Intenzivní mezinárodní spolupráce s pracovišti pedagogického výzkumu se orientovala především na progresivní pedagogiku reprezentovanou akademiemi pedagogických věd v SSSR 
a NDR a dalšími centry v Mad’arsku a Polsku. Spolupráce se sovětskými pedagogy, překlady a interpretace prací předních didaktiků a pedagogických psychologů (Elkonina a Davydova, Leont'jeva ml., Lernera, Zankova, Skatkina) a společné československo-sovětské semináře byly součástí vědeckých a organizačních aktivit, kterými se Jan Průcha zabýval. Př́nosná byla kooperace s Ústavem experimentální pedagogiky Slovenské akademie věd, kde se přátelské vztahy se slovenskými kolegy promítly i do badatelských projektů a série společných seminářů, které Jan Průcha organizoval.

Vstupy do reálného prostředí školy, v době normalizace a dominující normativní pedagogiky nepř́liš žádoucí, využil Jan Průcha prosazením rozsáhlého empirického výzkumu realizace obsahu vzdělávání ve výuce (pozorování 110 vyučovacích hodin v ZŠ a G), jehož kritické výsledky publikoval ještě před sametovou revolucí (Pedagogika, 39/2/, 1989). K novým tématům, která otevřel, patřilo hodnocení učebnic inspirované metodologií estonského pedagoga J. Mikka. $V$ tehdejším národním podniku Učební pomůcky inicioval a koordinoval program zaměřený na tvorbu a hodnocení učebnic, $k$ němuž se připojila řada českých pedagogů. Oslovila jej také sovětská prognostika, hlavně práce $B$. S. Geršunského, s nímž navázal odborné i osobní prátelské kontakty. Paralelně studoval západní futurologii a projekt Evropa 2000, kde hledal odpovědi na otázky budoucnosti školy a vzdělávání, což se promítlo do několika jeho odborných publikací. Díky odvaze nakladatelství Mladá fronta byly knihou Rok 2000: Budeme celý život žáky (1983) úvahy o budoucnosti vzdělávání zprostředkovány $\checkmark$ popularizační formě české veřejnosti. Tato knižka byla první mojí společnou publikací s Janem Průchou a začátkem odborné spolupráce, která pokračovala v dalších dekádách. V závěru osmdesátých let získal Jan Průcha v tehdejší Československé akademii věd hodnost doktora věd.

Dramatická a nadějná devadesátá léta 20. století otevřela českou pedagogiku světu a Janu Průchovi přinesla nové př́ležitosti. Stal se zakládajícím ředitelem Ústavu pedagogických a psychologických výzkumů (ÚPPV) na Pedagogické fakultě UK. V jeho koncepci měl být ústav výzkumným pracovištěm s interdisciplinární bází $\checkmark$ pedagogice, psychologii a sociologii. Ústav se pod jeho vedením aktivně zapojil do revitalizace pedagogických věd a výrazně přispíval zejména ke srovnávací pedagogice a navazování mezinárodních kontaktů. Stal se centrem diskusí se zahraničními odborníky, podílel se na př́pravě 8 . světového kongresu srovnávací pedagogiky (1992). V autorské dvojici Průcha-Walterová vznikla také publikace Education in a changing society: Czechoslovakia ( $\mathrm{H} \& \mathrm{H}$ 1992), která měla informovat nové zahraniční partnery o našem vzdělávacím systému, jeho historii a hodnotách, problémech a perspektivách. Pod editorstvím Jana Průchy vznikly v širším týmu ÚPPV práce seznamující českou odbornou veřejnost s pedagogickým výzkumem, vzdělávací politikou a školstvím v západních zemích.

$K$ revitalizaci a mezinárodní prestiži české pedagogiky, $v$ předchozím období zatížené politickou a ideologickou závislostí, normativností a generační diskontinuitou, zásadně přispělo založení České asociace pedagogického výzkumu (ČAPV) $\checkmark$ roce 1992, jehož hlavním iniciátorem Jan Průcha byl. V programovém referátu na první konferenci asociace formuloval cíle a úlohy pedagogického výzkumu v teorii 
106 a metodologii, evaluaci, vztahu k praxi a vzdělávací politice i v př́pravě nové vědecké generace. $\mathrm{K}$ naplňování cílů osobně přispíval jako zvolený předseda asociace (1992-1996) a i v dalších letech, kdy byl jejím čestným předsedou. Vystupoval na konferencích s výstižnými plenárními referáty, kriticky analyzujícími stav pedagogického výzkumu a přinášejícími impulzy pro jeho další rozvoj.

V aktivně rozvíjených mezinárodních vazbách Jana Průchy dominovaly severské země, zvláště Finsko. Přednášel pravidelně zejména na Univerzitě v Turku, na které mu byl v roce 1995 udělen čestný doktorát. Na Pedagogické fakultě UK v Praze se $\checkmark$ roce 1992 habilitoval a o dva roky později byl jmenován profesorem na Univerzitě Karlově.

Oproti úspěchům v externím prostředí se méně dařilo v domovské instituci. ÚPPV nenaplnil představy interdisciplinárního vědeckého pracoviště, postupně jej opouštěli jeho pracovníci, nakonec i ředitel. Torzo ÚPPV přežilo krizi a posíleno novými pracovníky se transformovalo do následnické instituce, kterou je současný Ústav výzkumu a rozvoje vzdělávání (ÚVRV). V porevolučních letech vznik a zánik institucí nebyly nikterak výjimečné, byl čas kvasu a hledání, příznačného pro transformační proces. ÚVRV se však ke svému zakladateli hlásí, ostatně profesor Průcha má dosud $\checkmark$ ústavu svou poličku na poštu a vzkazy. Kdykoli se objevil, byl srdečně vítán a jeho př́tomnost vyvolala neformální diskuse na odborná témata a aktuální problémy ve školství.

Po odchodu z pedagogické fakulty působil profesor Průcha několik let na katedře andragogiky Filozofické fakulty UK a přednášel na dalších pedagogických pracovištích. Institucionální a administrativní povinnosti však považoval spíše za př́těž než za podmínky zajišt’ující pracovní zázemí. Dal tedy přednost nezávislosti, v níž spatřoval sice nelehkou, leč vhodnější možnost pro realizaci svých odborných ambicí. Jako nezávislý odborník v posledním čtvrtstoletí života vydal své zásadní publikace, přičemž na některých z nich pracoval s dalšími autory, které ke spolupráci vyzval. Patří k nim výkladový Pedagogický slovník (Průcha, Walterová, Mareš, první vydání Portál 1995), určený širšímu okruhu uživatelů. Slovník zaznamenal sedm aktualizovaných vydání, poslední v roce 2013. Řadí se $\mathrm{k}$ nejžádanějším publikacím nakladatelství Portál, jehož kmenovým autorem se Jan Prưcha stal a kde působil i jako předseda vědecké rady. Významnými počiny byly tituly Moderní pedagogika (Portál 1997) a Vzdělávání $a$ školství ve světě (Portál 1999). K charakteristickým rysům těchto i dalších Průchových publikací patř́ systematičnost, srozumitelnost explikací, přehledná struktura usnadňující orientaci v textu a zakotvení v realitě, za jejímž poznáním se skrývá autorova náročná heuristická práce. Uvedené práce zaznamenaly čtenářský úspěch, vyžádaly si dotisky, aktualizovaná a rozšiř̌ená vydání, včetně elektronických knih a modifikací ve formě učebnic, např. Přehled pedagogiky (Portál 2000) a Srovnávací pedagogika (Portál 2006), které „provázejí studenty po celou dobu jejich studia“, jak mi napsal jeden $z$ nich.

Další výzkumné a publikační aktivity rozvinul Jan Průcha ve více liniích. Slovníkové práce zahrnují Česko-anglický pedagogický slovník (ARSCI 2005), Česko-anglický slovník - pedagogika, školství, andragogika (Paido 2011) a Andragogický slovník 
(Grada 2012, spoluautor J. Veteška). Sledování vývoje pedagogiky a trendů ve vzdělávání v mezinárodním i národním kontextu vedlo $\mathrm{k}$ titulům zacíleným na nově se vynořující témata a disciplíny, dřive méně rozvíjené. Patři k nim Multikulturní výchova (ISV 2001), Interkulturní psychologie (Portál 2004) a pozdější Interkulturní komunikace (Grada 2010). Zájem o vývoj a vzdělávání dětí v předškolním období se promítl do práce Dětská řeč a komunikace (Grada 2011), objasňující proces osvojování jazyka a komunikačních schopností u dětí na základě psycholingvistiky, kdy Jan Průcha navázal na své odborné začátky. K rozvoji předškolní pedagogiky přispěl publikací Předškolní dítě a svět vzdělávání (Wolters Kluwer 2016), k níž přizval další odborníky v preprimární pedagogice a navázal na dřive vydanou učebnici Předškolní pedagogika (Portál 2013, spoluautorka S. Kotátková). Věnoval se i druhému pólu celoživotního vzdělávání a učení. Knihou Andragogický výzkum (Grada 2014) přispěl k systematizaci teoretických východisek a metodologických základů andragogiky jako empiricky založené vědy. K Průchovým pracím v posledním pětiletí přibyla také publikace Česká vzdělanost (Wolters Kluwer 2015) usilující o objasnění komplexního kulturního fenoménu z dílčích aspektů vybraných vědeckých disciplín. Komparatistické práce Jan Průcha doplnil příspěvkem do edice Školní vzdělávání v zahraničí publikací Školní vzdělávání ve Finsku (Karolinum 2015, spoluautor P. Kansanen) a encyklopedickým přehledem Vzdělávací systémy v zahraničí (Wolters Kluwer 2017), popisujícím vzdělávací systémy v Evropě, USA a Japonsku. V titulu Odborné školství a odborné vzdělávání (Wolters Kluwer 2019) se Průcha zaměřil na oblast, kterou dlouhodobě sledoval, považoval za výzkumně podceňovanou a vyzýval opakovaně k jejímu intenzivnímu výzkumu. $V$ závěru této monografie formuloval návrhy na systematický výzkum odborného vzdělávání a vybudování infrastruktury umožňující jeho realizaci a prezentaci. Inicioval a editoval také monotematické číslo Odborné školství a odborné vzdělávání: Současné teorie a výzkumy (Pedagogika, 69/2/, 2019), kde shromáždil pozoruhodný soubor výzkumných nálezů a informací o vědeckých aktivitách v oblasti odborného školství.

V poslední vydané publikaci Psychologie učení (Grada 2020) věnuje Jan Průcha značnou pozornost vývoji a trendům ve výzkumech učení, jejich metodám a výsledkům $\mathrm{s}$ důrazem na vztah $\mathrm{k}$ edukačním procesům $v$ reálném prostředí životních situací, rodiny a zejména školy a třídy. Lze ji považovat také za pomyslný vrchol autorova hledání odpovědí na otázky smyslu vědeckého bádání. S překvapivou pokorou a uvědomovanými limity uznává potřebu interdisciplinárního a týmového zkoumání. V srpnu 2021 vychází ještě Průchova komparatistická publikace USA: Školství a vzdělávání v kulturním kontextu (Wolters Kluwer), avizovaná jako ucelený popis reality vzdělávacího systému $v$ širších sociálních souvislostech. Nepochybně i o ni projeví zájem četní čtenáři.

Pozemská cesta Jana Průchy se završila. Svým dílem a iniciativami v odborné komunitě zanechal hlubokou stopu a jeho publikace se staly součástí zlatého fondu české pedagogiky. Jeho profesní zaujetí se vyznačovalo mimořádnou vitalitou a neúnavnou pracovitostí, výsledky systematičností a pozoruhodnou senzitivností pro problémy vzdělávací reality. Odešel jeden z posledních př́islušníků generace, která 
108 procházela peripetiemi společenských změn druhé poloviny 20. století a až ve zralém věku se jí dostalo možnosti plně prokázat své potenciality ve svobodné vědě. Jan Průcha dal přednost nezávislému bádání. Z nelehké pozice solitéra se mu podařilo realizovat nejen vlastní profesní záměry. Inicioval a realizoval úkoly pedagogického výzkumu s dalšími odborníky, které si ke spolupráci cíleně vybíral. Př́kladem byla součinnost na vpravdě titánském díle, kterým je rozsáhlá Pedagogická encyklopedie (Portál 2009, 935 stran). Jan Průcha tento projekt připravoval několik let, tři roky věnoval jeho realizaci. Na textech se podílela stovka autorů a Průcha jako editor v kooperaci s hlavními konzultanty Tomášem Janíkem a Miladou Rabušicovou ř́dil realizaci projektu a garantoval kvalitu textů. Encyklopedie je ojedinělým syntetickým a systematickým dílem, prezentuje odborné poznání české pedagogiky na počátku 21. století. Její hodnota a význam pro českou pedagogiku jsou neocenitelné a trvalé. Je nám nesmírně líto, že nás Jan Průcha opustil, jeho přítomnost nám bude chybět, ale jeho odkaz je s námi, zůstává otevřený pro současníky i pro další generace, které ocení jeho hodnotu i v budoucnosti.

Eliška Walterová předsedkyně redakční rady Orbis scholae eliska.walterova@pedf.cuni.cz 